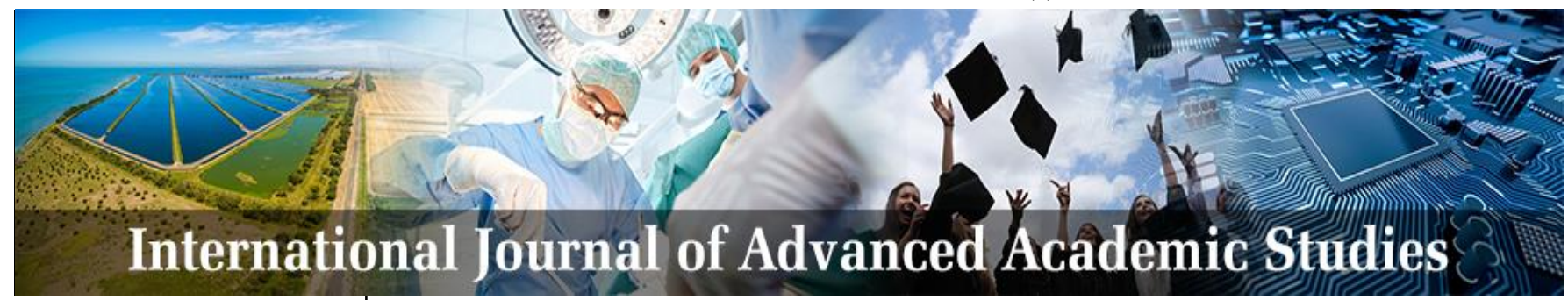

E-ISSN: 2706-8927

P-ISSN: 2706-8919

www.allstudyjournal.com

IJAAS 2021; 3(1): 192-203

Received: 08-11-2020

Accepted: 14-12-2020

Mohammad Najim Wahedy* Associate Professor of school of construction management, Kabul Polytechnic University, Kabul, Afghanistan.

\section{Amanullah Faqiri}

Professor of school of construction management, Kabul Polytechnic University, Kabul, Afghanistan.
Corresponding Author: Mohammad Najim Wahedy Associate Professor of school of construction management, Kabul Polytechnic University, Kabul, Afghanistan.

\title{
Proposed competencies required for construction project managers in Afghanistan
}

\section{Mohammad Najim Wahedy and Amanullah Faqiri}

DOI: https://doi.org/10.33545/27068919.2021.v3.i1c.485

\begin{abstract}
The nature of projects is always dynamic, complex, and different from each other. Project lifecycle is along with risk, changes, uncertainty, and even sometimes not succeed. Therefore, to bridge these gaps in Afghanistan context and to achieve the project goal within budget, time, scope, and quality. All projects-oriented organizations such as construction firms, consultancy firms, and information and communication technology (ICT) firms, need project managers with leadership and management competencies or skill sets to complete projects successfully. Leadership and management competencies are combinations of knowledge, skill sets, leadership styles, including technical, emotional, behavioral abilities which elaborated in this paper. These traits are compiled and analyzed through a comprehensive study of related research papers, standards, and relevant institutions for project management, that reflect the intent of this paper.
\end{abstract}

Keywords: Project manager, leadership, management, competency, construction project, project success

\section{Introductions}

"Project Management is the application of knowledge, skills, tools, and techniques to project activities to meet the project requirements" as defined by Project Management Institute (PMI). The success of the project is a major concern in the field of project management and a recurrent theme in literature. The evaluation of performance (success criteria) and the factors leading to the success of projects (success factors) are two major aspects of this issue. The question about the competence of the project manager is closely linked to this. The project manager's experience is really an element to the successful execution of projects and, from the other side, the project manager requires to provide knowledge and skill in certain fields that have the greatest effect on successful results. For years, the definition for competency is indeed wide, vague or elusive. ${ }^{[2,3]}$. Even so, the integration of knowledge experience, ability, and behavior is perhaps the most broadly agreed concept of competency ${ }^{[4-8,3-7,9-12]}$. Around the world, there are plenty of descriptions of the word 'competence' The IPMA Individual Competency Baseline (IPMA ICB) provides a simple English explanation generally agreed by practitioners as well as expected to be identifiable or easy to understand. This explanation is not aimed at minimizing or override some other descriptions but instead may provide the person who needs enhancement with guidance. "Individual competency is the application of knowledge, skills, and abilities in order to achieve the desired result" [13]. ${ }^{[14]}$ Project manager competence has been considered to consist of knowledge information (qualified), abilities (able to perform work) and key characteristics of personality (aspirations + talents + system thinker) which because Crawford claimed, that the project management personnel and good performance of project strongly interdependent and so the project manager's expertise in itself is key to the success of the project accomplishment ${ }^{[15]} \mathrm{He}$ was a professional in the area; he said the abilities of a manager may have a significant effect on performance, and his views later inspired other practitioners Competency Leadership School (CLS) has since been developed the definition of competency and united previous concept and meaning model of competency such as (emotional intelligence, trait, contingency, many research papers have culminated in rankings of skills important to managing projects $[2,3,19$ 22]. Furthermore, Project Management Competency Development Framework (PMI, 2013) and International Project Management Association Competence Baseline were developed by Project management Organizations/institutions for the management of Some researchers wrote that various positions require unique skills so the project leaders required a range of skills to be successful and lead to the success of the project. 
Academic studies assert that "depending on the requirements for success, different sets of competencies comprise different success profiles" [11, 27] A productive project manager at the same time has to be a successful communicator, mentor, coordinator, manager, and leader to achieve the project goal within defined scope and Project leadership requires the ability to answer with minimal stress to unclear or vague circumstances. They need to interact with project members and be trained in different techniques of influence to people performance ${ }^{[28]}$. Planning, leading, facilitating, and controlling a different and intricate set of processes and individuals are a continuous effort of project management to achieve the project Such efforts required leadership and management competencies and skills for project managers to communicate and interact with project stakeholders to make the right These managers need to be able to deal and communicate with various types of people and use the project team's diversity. The leadership style of the project managers affects the performance process and project success ${ }^{[26]}$. In addition, according to ${ }^{[29]}$, in project management practice Staff or labor abilities have a significant impact than technical abilities. One of the reasons in various projects that cause the management to be unsuccessful will be hiring an inexperienced project manager. Hence, good project management needs to wisely choose and hire a qualified project manager [30]. Consideration of managers' competence throughout the successful delivery of projects is demonstrated by not only studies through project victory and different points of view of project management competence but also by the establishment of guidelines that would be utilized to instruct the development and evaluation of project There are two key areas of standards concerning aspects of project management competence, first, those belong to project managers required to know about and defined by the project management body of knowledge standards book (PMbok), second, those belong to project managers required to be tenable to do, that mainly come in the form of fulfillmentbased or occupational competency standards. The followings are four worldwide acknowledged project management knowledge standards $[10,1,31]$.

a) Project Management Institute (PMI) PMBOK standard (2017)

b) International Project Management Association (IPMA2015)-ICB

c) Association for Project Management APM BoK /CRMP BoK - (Morris2000)

d) The Australian Institute of Project Management (AIPM, 2004)

The objective of this review will be to study the most relevant competencies of the project manager (emotional, managerial, and behavioral) and characteristics of leadership are demonstrated by the Project Managers in projects that are successful, based on the specific context and project types that already investigated and identified by researcher and academician, which will be used in recruiting the project managers, as an outline to be thought for capacity building of project managers and successful delivering of projects.

\section{Method of study}

The method which is used in this research is the descriptive analytical method, that information, data and subjects are compiled from research papers, dissertations, project managements' standards, guidelines and institutions, that all are valid scientific sources. All required management and leaderships competencies of literature reviews studied, analyzed and presented in simple arrangement, that include plain text, bullet point, tables, graphs and figure. The bibliography of this study is also prepared and incorporated in references for more curious studies.

\section{Project Manager's Competencies}

The skill-based model goes back to the time in the 1970s, since, due to the rapid changes in knowledge, hiring procedures were still related to the job requirements ${ }^{[4]}$. The idea of competence was the solution to replace the constantly evolving old-fashioned job requirements with other methodology based on employees' abilities ${ }^{[4]}$. For years, the definition of competency has indeed been wide, uncertain, and dispersed ${ }^{[2,3]}$. Even so, the blend of skill, behavior, and knowledge is the most generally acknowledged concept of competency $[3,5-7,9-12,26]$. The word 'competence' is interpreted in many ways all over the globe. The IPMA Individual Competency Baseline (IPMA ICB) provides a simple English explanation generally agreed by practitioners as well as expected to be identifiable or easy to understand. This explanation is not aimed at minimizing or override some other descriptions but instead may provide the person who needs enhancement with guidance. "Individual competency is the application of knowledge, skills, and abilities to achieve the desired result. [13]",

Knowledge: It is the set of knowledge and practice that a person owns. Knowing the idea of a Gantt chart, for instance, maybe called knowledge. Skill Unique technical tenability that allows a person to accomplish work is called skill. For instance, it could be assumed a skill to construct a Gantt chart. Ability, is the efficient application of knowledge and skills in a specific scenario. For instance, the capability to develop and effectively control a project schedule may be accounted ability ${ }^{[13]}$. According to ICBIMPA-2015 project manager's competencies has three aspects: intellectual, managerial, and emotional. A much more collaborated dissect review showed that all three leadership aspects (EQ, MQ, IQ,) responding separately to the success of the project ${ }^{[32]}$. Critical analysis, strategic viewpoint, and self-vision are comprised in the Intelligence Quotient (IQ). The Management Quotient (MQ) comprises interconnection, resource management, team achievement, growth, and empowerment. Personality, openness to intuition, and governance is the aspects of emotional quotient (EQ) (inspiration and conscientiousness included) ${ }^{[32]}$. ICB-IMPA-2015 ${ }^{[13]}$ proposed three aspects of project manager competencies. 


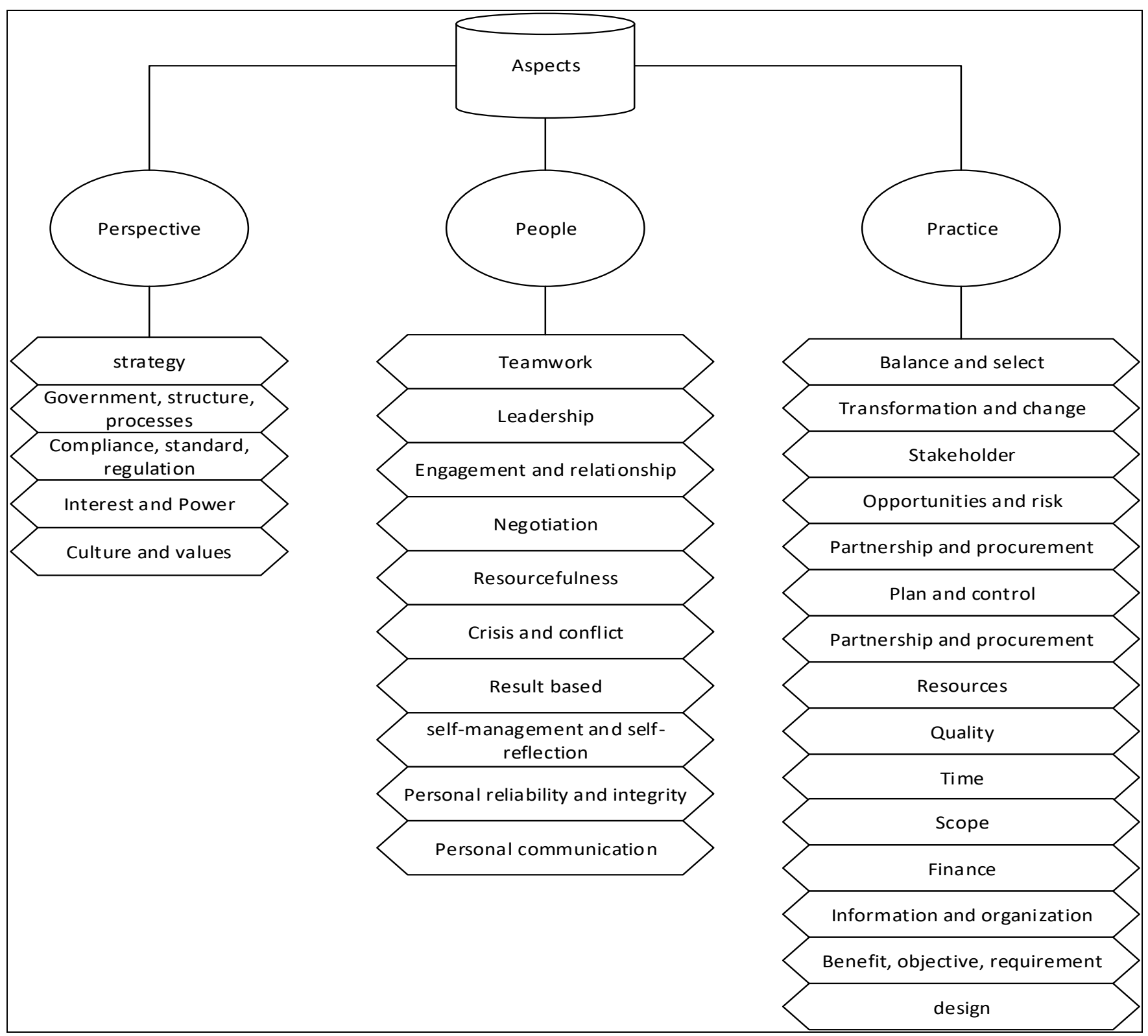

Fig 1: Project Manager's Comptetencies

Research results by [26] indicated the high effect of (critical thinking) which is one of the IQ subdomain and (conscientiousness, inspiration, and influence) which are the three subdomains of EQ outside of fifteen competencies in each kind of project to accomplish them successfully.

Table 1: Three styles and fifteen competencies of leadership ${ }^{[33]}$.

\begin{tabular}{|c|c|c|c|c|}
\hline Domain & Competencies & Involving & Engaging & Goal Based \\
\hline \multirow{4}{*}{ Managerial Quotient } & Engaging communication & Average & More & Average \\
\cline { 2 - 4 } & Managing resources & Average & Less & More \\
\cline { 2 - 5 } & Empowering & Average & More & Less \\
\cline { 2 - 5 } & Developing & Average & More & Average \\
\cline { 2 - 5 } & Achieving & Average & Average & More \\
\hline \multirow{5}{*}{ Emotional Quotient } & Conscientiousness & More & More & More \\
\cline { 2 - 5 } & Self- awareness & More & More & Average \\
\cline { 2 - 5 } & Intuitiveness & Average & More & Average \\
\cline { 2 - 5 } & Emotional resilience & More & More & More \\
\cline { 2 - 5 } & Motivation & Average & More & Average \\
\cline { 2 - 5 } & Sensitivity & More & More & Average \\
\hline \multirow{4}{*}{ Intellectual Quotient } & Influence & Average & Average & More \\
\cline { 2 - 5 } & Critical analysis \& Judgment & More & Average & More \\
\cline { 2 - 4 } & Vision and imagination & Average & Average & More \\
\cline { 2 - 5 } & Strategic perspective & &
\end{tabular}


Engagement is a style focused on motivation and participation in an extremely transformative way. This style of leadership focuses on producing real change through dedication and involvement. Involvement is a method for transactional enterprises that face a major, but not inherently drastic, a shift in their business strategy or work style. GoalBased in a relatively stable setting, it is a style, based on producing correctly defined outcomes. ${ }^{[25]}$ Discovered that out of following Project Manager's leadership competencies Conscientiousness has the highest contribution to project success. (Sensitivity, emotional resilience, motivation, influencing, Conscientiousness, intuitiveness, and selfawareness) ${ }^{[34]}$. Identified and prioritized the construction project manager's competencies as follows:

\begin{tabular}{||c|c||}
\hline $\begin{array}{c}\text { Project manager's } \\
\text { competencies }\end{array}$ & Leadership \\
\hline & Managerial \\
\hline Compressional \\
\hline Commension \\
\hline
\end{tabular}

Fig 2: Project Manager's Comptetencies

However, ${ }^{[35]}$ stated that It also is possible that the project manager's leadership style and expertise have little effect on the outcome of the project, and indeed the specialty, unique and temporary context of projects (and also the risk related) implies that perhaps the leader will have less influence the results. Though this will only have a positive effect if it is measured directly. The below competencies and skills are needful for a good project manager [36]: Versatility and compatibility, essential leadership and ingenious style, hostility, trust, reasonableness, power of verbal persuasion, passion, a large variety of personal interests, Energy, power, efficacy as an orator and operator, dignity, excitement, creativity, immediacy, ability to integrate cost, time and human factors with practical solutions, Highly planned and managed, able to do every job rather than a specific job, Capable and prepared to spend much from his or her hours' scheduling and managing, Capable for finding challenges, know how to make choices, capable of keeping a good equilibrium in the use of hours. Similar to ${ }^{[37]}$ the most critical qualities of project leaders for the successful delivery of projects in a conventional world of skills are: technical competencies, managerial competencies, negotiation, collaboration, teamwork, personality, interpersonal. The leadership styles of more and less active project managers have been found to vary, and Intelligent Quotient (IQ) appears that it is more popular than Emotional Quotient (EQ) ${ }^{[32]}$. Failure and success of the projects are relevant to the Leadership style and competencies of project managers. Project management leadership requires different strategies used by managers to help them to respond to each and every condition. ${ }^{[38]}$. Some researchers have established a distinction for both project management and leadership. Leadership focuses also on the capacity to inspire individuals to really do well or to work for mutual objectives to ensure results or project leadership includes inspiring, leading, and directing individuals to accomplish organizational objectives. Management of the project includes planning and coordinating project tasks ${ }^{[8,39]}$. There are three different categories of project leadership. First, style of leadership, second, leadership behavior, and third, leadership characteristics ${ }^{[40]}$. Styles of leadership are the way of classifying different forms of leadership roles and how project managers behave with other project participants. [41]. Participatory, transactional and transformational are the three forms of management styles. [39]. Transactional leadership significantly affected the effectiveness of leaders by way of combined efficiencies and transformative leadership was the most favored type of leadership ${ }^{[42]}$. The authors noted that, according to two presumptions, leadership is needed for project managers: first, leaders or project managers will dramatically affect the performance of team members and second, successful leaders inspire team members to achieve the related objectives of the organization ${ }^{[43,44]}$ Tried to explore the correlation between both global leadership and the evolution of characteristics throughout practice and experience. Internationalization requires the active corporation of leaders to direct supporters to multiculturalism for overseas projects to become successful ${ }^{[39,45]}$. Internationalization is an evolving mechanism. Internationalization into a global network of contact and business is the convergence of, communities, cultures, and economies. [44,45]. Business leaders also moved forward into internationalization in the 21 st century to drive global projects and requesting leaders with skills to adjust to cultural and racial awareness and inclusivity ${ }^{[44]}$. International and new leaders, handle staff and organizational based project beyond the continents, culture, and language. The following seven types of global leadership skills are ${ }^{[44]}$.

a) Understanding (knowledge) and capabilities (skill)

b) Sensitivity and Knowledge of culture

c) Social interaction (communication)

d) Worldwide Perspective

e) Attitudes or traits

f) Relationship preservation and improvement

g) Lessons learning from performance

Contradictory ${ }^{[41]}$ Leadership features and skillsets were defined as two dimensions of effective leaders' traits. They found that leadership characteristics or traits resulted in a trivial amount to the areas of leadership efficiency. Efficient leadership relies on leaders' ability to change their approaches (leadership style), attitudes, and attributes to suit the condition ${ }^{[46]}$. Depending on the project's nature, project managers may use the three leadership styles. Project management leadership comprises various strategies to adapt to each condition ${ }^{[38]}$. Mr. Senthill ${ }^{[39]}$ proposed that managers tailor a style of leadership as per the given situation to achieve the goal. A set of skills (competencies), enabling the project team to have a positive effect on the results of the project. The success of a project manager is belonging to the project team, if the project team is good so the project manager is successful as well ${ }^{[47]}$. Explained three basic styles of leadership: (a) psychosocial (emotional), (b) directorial (managerial), and (c). Cognition (intellectual). To know distinctive views [47], gathered information and data about styles of leadership of projects, 
these data collected from member involved in projects, including managers, owners, and team members. Project leadership competencies should comprise the below skills from the viewpoint of the project manager: (a) to achieve project goal successfully buildings teams in divisions and subdivision is necessary and (b) communicate or negotiate across various geographies, communities, and time zones. According to the client or project owner's viewpoint, the following sets of skills and abilities should be demonstrated by the project leader: (a) Keep a record of projects' progression, (b) Accurately discussing objectives, and (c) determine the obvious or clear objective. According to the project team's viewpoint the following sets of skills and abilities should be demonstrated by the project leader: (a) Ensuring the free flow of information and communication, (b) measure record of projects' progression, and (c) make sure targets comply by project teams. And also he explored that planning and information discussion (communication) is a usual qualification of project leadership ${ }^{[48]}$. The link between Project Managers actions and management expertise models and project victory in a comprehensive approach culminated and discovered that Project managers with a broader set of skills distinguished by a higher rate of social awareness (emotional), system control (managerial), and values appreciation or openness (behavioral) capacities enjoy greater project's success. Specifically, skills pertaining to related to effectiveness, openness, and values admiration (behavioral skills), control of the system, customer support and group work (managerial), and sociable capacity (emotional) and also the project leadership style appeared to better demonstrate the deficiency among project managers involved in more prosperous projects versus their competitor. The below table explains elaborately the competencies of project managers.

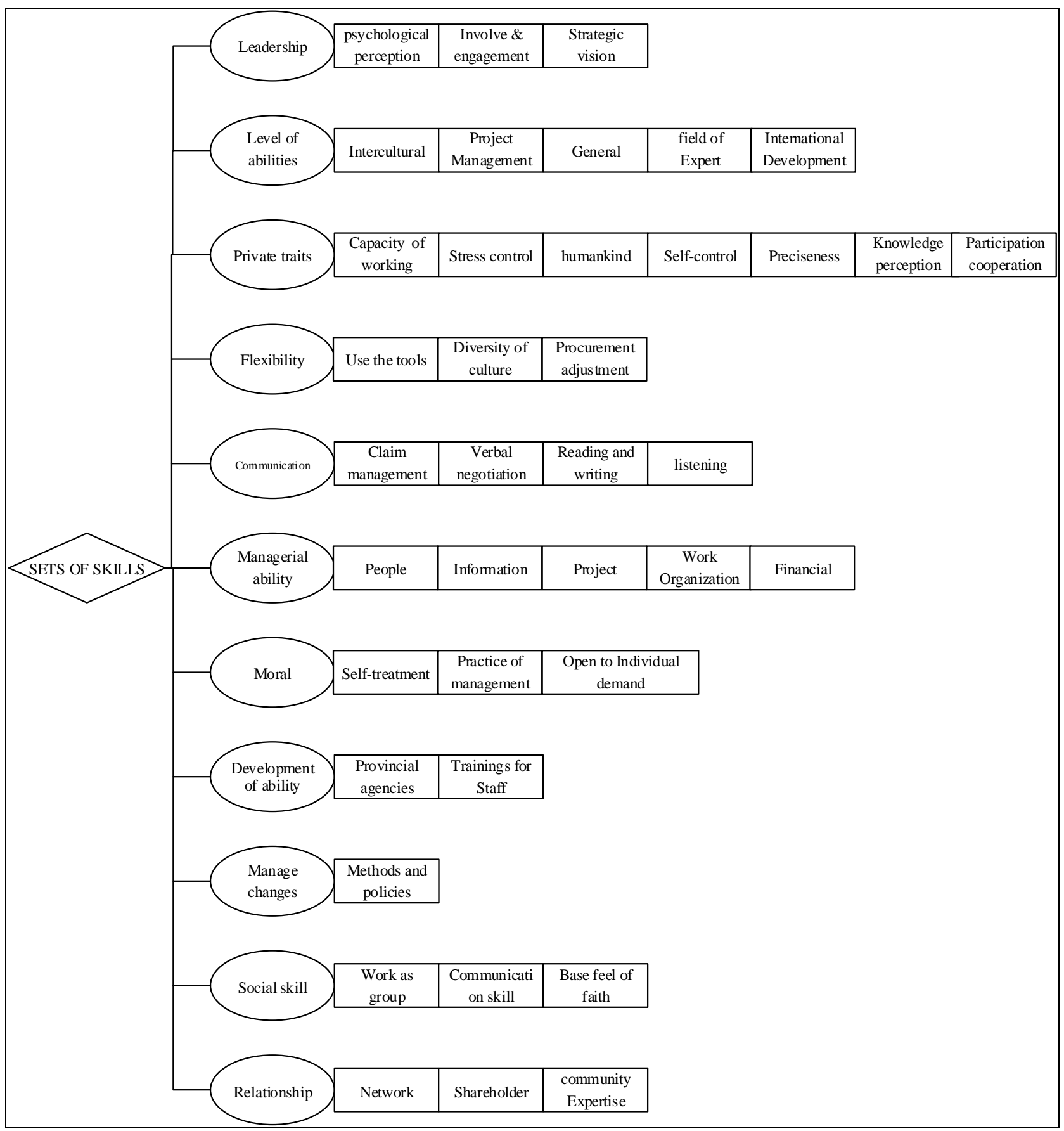

Fig 3: Project manager's detail of competencies in international non- organizational government (NGO) ${ }^{[17]}$ 
Table 2: Behavioral, Managerial and Emotional Competencies of Project Managers ${ }^{[47]}$

\begin{tabular}{|c|c|c|}
\hline Behavioral Competences & Managerial Competencies & Emotional Competencies \\
\hline Leadership & Interpersonal relationship & Self-awareness \\
\hline Engagement \& Motivation & Teamwork & Self-management \\
\hline Self-control & Personal development & Social awareness \\
\hline Assertiveness & Managing future & \multirow{2}{*}{ Relationship management } \\
\cline { 1 - 1 } Relaxation & \multirow{2}{*}{ Promoting continuous improvement } & - \\
\hline Openness & Fostering innovation & - \\
\hline Creativity & Competitiveness & - \\
\hline Results orientation & Energizing & - \\
\hline Efficiency & Customer service & - \\
\hline Consultation & Acculturation & - \\
\hline Negotiation & Controlling the system & - \\
\hline Conflict and crisis & Coordination & - \\
\hline Reliability & & - \\
\hline Value appreciation & &
\end{tabular}

[49] The Project Management Competency Development concept was extended to the skills desired by project managers through the application of the PMI Skill Pyramid in recent PMI research. The pyramid of skill consists of the three main qualifications: (a) managing of technical aspects of the project, program, and portfolio is the relevant skills required to a particular domain of projects such as knowledge and information, Behavioral traits, and sets of skills. Working as technical responsible to fulfill the project objectives. Leadership means to agitate and guide a group to help an organization gain its objective through the knowledge and information, Behavioral traits, and sets of skills. Business management and Strategic are the market and corporate experience and skills that enhance efficiency and achieve business results faster. According to researchers, project manager's competencies in an organization divided into three sections [3, 6, 57-65, 29, 50-56]. Institutional and managerial competencies include: Starting to plan and coordination, identify and clear solution for a problem, supplying outcome, portfolio, program, and project orientation, clear orientation of targets, strict decision and intensity in the intonation of speech, capacity to imagine the project's interaction with business and the environment, capacity to see the full scope of the project. Technical competencies/project management competencies include: project knowledge, engagement of involved stakeholders in project success, knowledge of techniques, strategies, and mechanisms, standard for project management of the project, specific understanding of technique and tools, computer usage capabilities, project management framework, project opportunity versus project risk, structure of the project, phases and schedule of a project, quality efficiency of organization in projects delivery, project deliverables and scope of work, requirement and expectation of project, administration of contract and logistic procedures, monitoring and recording, data gathering, analysis, reporting, recording, and communicating, financial management, expenditures, and resources, technical expertise, PMP certification. Human skill/behavior (skills sets) include: negotiation, moral and ethics, agitation, managing and leading of team working and team building procedures, innovation and ingenuity, relation and communication, mobilizing, to deal with conditions, assigning responsibility, enhance self-respect, passion, decision making, political awareness, engagement, selfcontrol, assertiveness, relaxation, openness, consultation, conflict and crisis management, reliability, human resource management, personal accountability, capable of slum dwellers, the mindset and capacity to cope with confusion and transition, capability to accelerate, length of prior engagements, intuition and improvisation, emotional intelligence, cross-cultural management, sustained improvement, troubleshooting of challenges, adjustment the usage of new tools, involve the participation of a large number of stakeholders. Furthermore ${ }^{[66]}$, groups skills into five major categories which is tabulated in table 5 .

a) Individual skill and self-imagination (skills 1-3)

b) Personal management (skills 4-12)

c) Cognitional ability (skills 13-15)

d) Agitation (skills 16-19)

e) Social skills or sympathy (skills 20-29) ${ }^{[67]}$

Table 3: List of Competencies (skills)

\begin{tabular}{|c|c|c|}
\hline S. No & Skills & Explanation Of Skills \\
\hline 1 & Believe and trust & Fairness and moral behavior \\
\hline 2 & Conscience assurance & A deep confidence in the capacity, skill, and conscience of someone \\
\hline 3 & Conscience appraisal & Understanding one's weaknesses and abilities \\
\hline 4 & Control rule & Consider over discipline, efficiency, and precision \\
\hline 5 & Adaptability & Flexible to changes \\
\hline 6 & Creativity & Be flexible and clear for any new concept and procedures \\
\hline 7 & Accountability & To be careful and accountable for its own individual results \\
\hline 8 & Looking for updates & Fulfilling the other's enthusiasm and desire for information \\
\hline 9 & Performance of Output & Do job rapidly and with excellent standard, \\
\hline 10 & Excellent resolving ability & Deciding with best of knowledge, studies and result obtained \\
\hline 11 & Control of job pressure & Capacity to manage the bad positons and work under any pressure and assignment \\
\hline 12 & Think critically & Systematic thinking of problem and analysis them logically to find the best solution \\
\hline 13 & Perceptual Thought & To recognize, utilize and describe ideas \\
\hline 14 & Language ability & Learn international languages and culture \\
\hline 15 & Success Oriented & Ability to strive for more successful outcomes \\
\hline
\end{tabular}




\begin{tabular}{|l|c|c|}
\hline 16 & Undertaking & Participate to the team or institution's objective \\
\hline 17 & Proposal & Identifying possibilities and working on them and finding the potential to make it possible \\
\hline 18 & Positivity & Despite challenges and losses, going to follow an objective \\
\hline 19 & Knowing everyone & Accepting, knowing, and respecting peoples' thoughts and opinions \\
\hline 20 & Working to Improve employees & Observing peoples' needs for growth and improving their skills \\
\hline 21 & Exploiting diversification & Establishing chances for organizations and companies to select various categories of staff \\
\hline 22 & Sophisticated in work environment & Know and use of company potential to accomplish goals \\
\hline 23 & Negotiation and correspondence & Trying to listen clearly actively and speaking plainly \\
\hline 24 & Managing disputes & Trying to solve disputes and addressing strategies \\
\hline 25 & Leadership & Managing tasks \\
\hline 26 & Management & Create and maintain meaningful social network and relation \\
\hline 27 & Develop connections and relation & Playing a partner role with everybody to achieve the objectives \\
\hline 28 & Cooperation and partnership & Capacity to accept and identify the other's emotions \\
\hline 29 & Empathic Consciousness &
\end{tabular}

Henry Mintzberg one of the management researcher's claims that updated managers need to focus on information, people, and action. According to ${ }^{[68]}$. The many interrelated tasks can also be immediately affected if unforeseen activities affect one of them. Therefore, it is important to fix challenges as early as possible to ensure project success. Although the success of the project relies on the participation of people who serve various fields and coordinate with various shareholders, cooperation is important for the successful recognition of challenges and also the fast preparation and seamless delivery of resolutions. Table 6 represents the major functions of project managers proposed by researchers.

Table 4: Project Management major functions Proposed by [68]

\begin{tabular}{|c|c|c|}
\hline Duties & Period of time & Key Activates \\
\hline Establish cooperation & $\begin{array}{c}\text { Less (At the project } \\
\text { initiation) }\end{array}$ & Pick the best persons. Establish confidence and shared interrelationship. \\
\hline $\begin{array}{c}\text { Incorporate training, study } \\
\text { and planning }\end{array}$ & Routinely & $\begin{array}{c}\text { Build long and adjustable plan and short fix plans. } \\
\text { Start understanding by project assessment. }\end{array}$ \\
\hline Avoid potential disturbance & Sometimes & Timely predict and manage deep challenges \\
\hline Keep movement progresses & Sometimes & $\begin{array}{c}\text { To find a solution for disputes with self-involvement, } \\
\text { communicate regularly via mutual meeting, maintain forward } \\
\text { development }\end{array}$ \\
\hline
\end{tabular}

Skills sets needed at the design stage for managers proposed by ${ }^{[69]}$, from the viewpoint of top management, the findings indicate that project management to have the below expertise to ensure the successful design process of a projects: understanding of huge contracts integration, understanding of the technical specifications of project building component, administration, and control of Professional efficiency of the design stage and understanding of project design specification, standards and guiltiness ${ }^{[70]}$. This is very clearly known that the skills of a person have a huge influence on their success. Although project managers' more common professional skill "hard skills" have attracted considerable focus, in this case, soft skill is not much important. Social skill sets, in particular, in the field of construction, a good skill set or competency pattern from HR management principles has been extracted in this research with a grounds for an analytical model for the analysis of the social skill sets of project managers in the construction industry. Four components of social skill sets (competencies) became defined for managers who work in the construction industry. Collaborating with each other, leading them, understanding people, and engaging stakeholders. Consideration to such qualities can assist managers to improve their social skill sets, which can lead to a higher result in his her job task and enhancing the efficiency of the whole company as well. The 9 components of the social competencies cluster, adapted from ${ }^{[71]}$. 


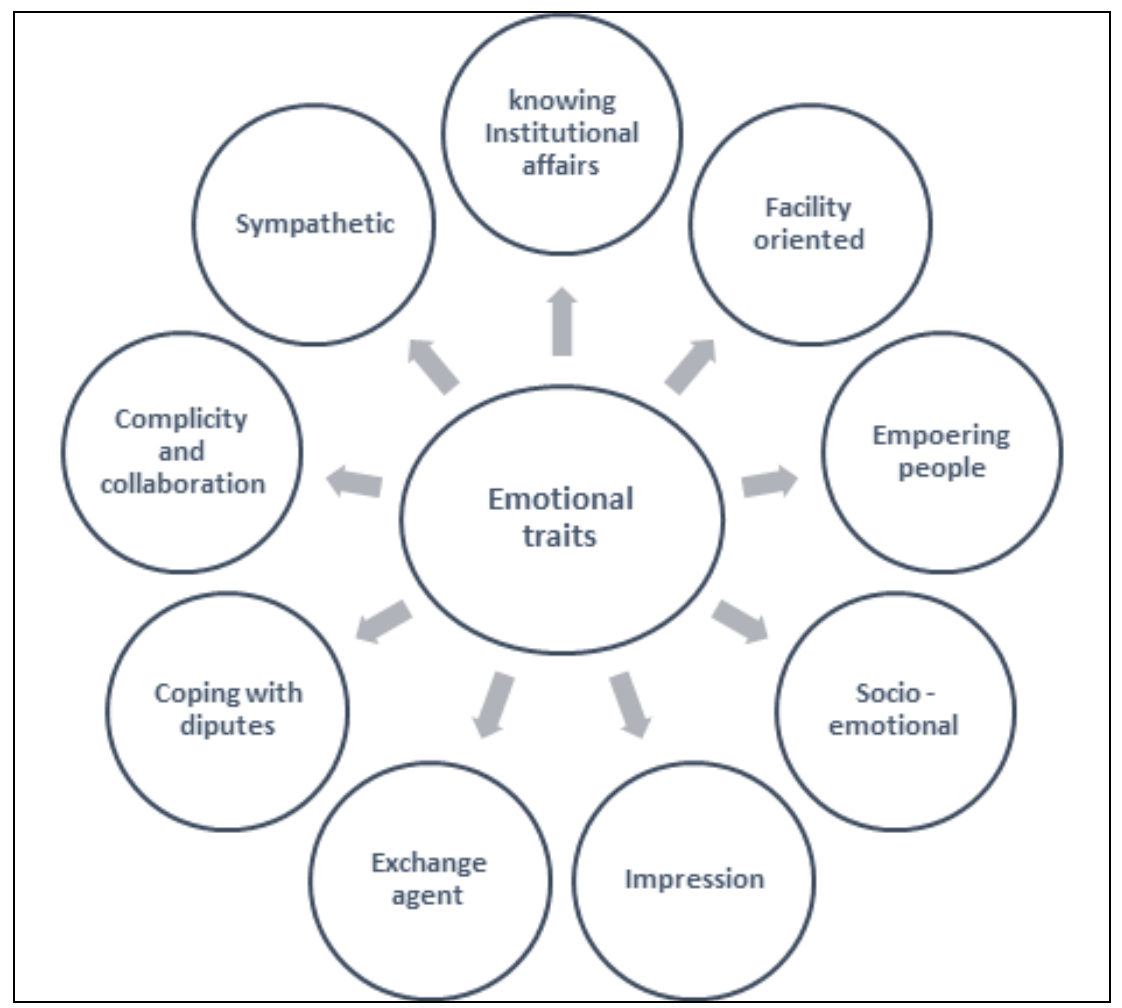

Fig 4: Aspects of emotional traits

The results of an exploratory study done by ${ }^{[72]}$ shows that following Project Manager Personality traits are very important in project success. Extraversion (Psychology), agreeableness, conscientiousness, emotional stability, openness.

[73-78] The much more significant features of a good project manager in the viewpoint of soft skills were defined by various experts as follows: Abilities of conversation, control of dispute, referred to customer, consistency, and traits of personality in leading, capabilities to build workgroup, ability to select the best choice among several options, emotional competency, troubleshooting of challenges and adaptable to each type of work. According to a paper by ${ }^{[79]}$ stated an important connection between the social maturity of managers and technical greatness. In general, to gain a competitive advantage and to be true leaders project managers must develop continuously "social maturity" abilities, which it is improve along with knowledgeability. Research by ${ }^{[51]}$ is revealing that the essential measure of goal achievements are: strong soft skills like negotiation ability, discussion, claim control, and convincing. It became quite apparent which project objectives can never be obtained with only the professional ability of the project manager ${ }^{[80]}$ as well as proposes a compromise among the professional areas of project management and leading skills and said that the priorities of the project manager are to develop group harmony and promote positive mutual partnerships, hence, all is indeed willing to collaborate towards a mutual objective which is finishing the project ${ }^{[81]}$. They explored that successful project management is a combination between managerial expertise and individual ability. And also, contend that management is not the same as leadership, both include separate traits, competencies, and knowledge and achieves their own objectives. The management works with the current situation, resources and facts, and leadership works with people, concepts or ideas, and future ${ }^{[82]}$. The focus on adaptive and versatile leadership methods or styles is superior than fixed and formal style, he said ${ }^{[51]}$. The author recommended that it be found to be able to succeed in project completion, if to each group of employee, within organization project managers apply the required style. Being one of the lowest qualifications for a project manager, technical capabilities are recognized. The appropriate criteria for efficient performance include outstanding social and soft skills, and while some might argue with that, some even suggest which these are abilities that may be developed or acquired rather than intrinsic or hereditary abilities. Results by ${ }^{[3]}$ suggested that six important key qualifications clearly defined by the research participants which became representative of crucial traits to successful project managers: The capacity for various levels of negotiation formal and informal based, mindset or the potential to cope with uncertainty, leadership, and change ${ }^{[83]}$. The findings of a study of top project managers have been published and explained that positive leadership causes successful delivery of projects and negative leadership vice versa. The attributes of leadership, later on, understood like, project spokesman, develop groups, provide objective, strong conscience, outcomeoriented, show faith and adaptability to any changes, display honor to others, the self-participant, strong standard of communication competency and encourages the development of junior employees, and also capacity to use management tools which are very important right now for every project manager. It is inferred that project managers need to integrate their professional expertise with the capacity to generate and demonstrate the best leadership style for intuitional effectiveness. According to ${ }^{[31]}$ a Delphi analysis which is an online-based study show which the experts rated the top 3 most important competencies of project managers as following: (a) understanding the project objectives (b) understanding the project scope of work, and (c) Complete job morally. The twelve Soft/Non-Technical (Interpersonal/People Management Skills) of the Project 
Manager's Competencies are identified as follows [84], communication ability, basic computer ability, ability to solve claims, able to judge and select the good choice, delegation ability, management support building ability, agitation capacity, communication capacity, coordination capacity, organizational politics skills, ability to find the solution, ability to develop working groups. A study on project manager's competencies working within the construction industry by ${ }^{[24]}$ explained that, although the employees' skill sets are extremely specific to the field in which he/she works, excellent project managers' interpersonal qualifications are often general in instinct and extend to a number of most other managerial roles. The findings by ${ }^{[24]}$ claim which senior managers exhibited a superb rate of twelve key (Behavioral proficiency or competency model), (a) inclination to result (skillful attitudes, further displaying efficiency growth and delivering different businesses with more innovative concepts), (b) ingenious (prompt efforts to prevent challenges in which to maximize project outcomes), (c) looking to find awareness (Prompt discovery beyond their close surrounding of challenges and strategies), (d) concentrating customer demands (attempts to satisfy your customer demands), (e) affect and impress (competency of harmonizing, team motivation and guiding), (f) directive ness (efforts to make sure which each employees meet their desires in the way anticipated), (g) collaboration and coordination (to influence the organization to behave in a favorable manner), leading of teams (realizing when not to respond officially and when to do, whether they try to get the most out of their fellows), creative speculate (reckon, study and thinking in terms of making reasonable choices among options for administration), consider conceptually (capability to see the wider image); personal control (remain cool and retaining consistency during difficult circumstances), and adaptive (staying versatile and dynamic to manage and find solution for challenges). business competency model suggested by ${ }^{[24]}$ :

a) To make sure that the project is adequately evaluated before starting

b) Providing the work with customer commitment and establishing close friendships for the next project

c) To keep financial audits and increase the profits of the organization.

d) Ensuring that the work is done under the quality standards of the contract

e) Ensuring that the output of the final result satisfies every requirement of stakeholders

f) Conforming to the requirements and standard of worker safety, health, and environmental aspects

g) Make sure that both workers and managers are mindful of their own positions and duties

h) Ensuring the documentation on project and other performance is accurate and efficiently shared with project stakeholders

i) Fostering performance progress by staff capacity building and professional growth

j) Develop and exchange information

k) Endorsing the principles and frameworks of organization

1) Make sure to participate and have the capacity for project bidding and proposals offering

m) Having control over advisory boards and organizing occasions n) Make sure to have a part in collaborating and harmonizing supply and delivering process management with your counterpart

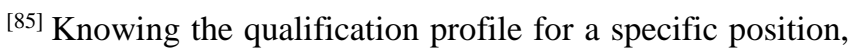
it really is necessary to recognize in which fields management staff has to be professional, (work qualification and skills) management staff must be professional and experienced, as well as the specific capabilities (interpersonal qualifications "behavioral" directly linked with the personal traits of management staffs) this makes them to really be productive and successful. The skills needed by the management team for the construction of the residential building in Ghana were proposed as shown below ${ }^{[86]}$.

a) Commitment to assisting suppliers in meeting work schedules

b) Effective time management on house-units

c) Managing schedule of work efficiently in house construing

d) Professional understanding and skills for site lining of housing projects

e) Simply access to the manager in Jobsite

f) Lesson learning of construction technology, experience and knowledge for next projects

g) Capability to manage claim, and disputes with finding best strategies and meanwhile to keep good connection with stakeholders

h) Freely to assist suppliers and other manufacturers to resolve their private issue

[87] A Ph.D. dissertation founded the most significant core skills required being an efficient project manager in the commercial construction sector in the United States (U.S.). Thirty-two of the competencies in this study are listed as "Hard Skill Competencies" and twelve were listed as "Soft Skill Competencies. The breakdown of the "Hard Skill" and "Soft Skill" competencies are as follow. Hard skill competencies include: building codes, building systems, business skills, business writing, computer skills, construction materials, construction management (management of the construction process), construction methods, construction safety, construction surveying, contract administration, contract documents, contract law, cost accounting, equipment utilization, estimating, graphics, human resources, job site layout, labor relations, managerial accounting, marketing, negotiation, organizational management (management of the organization), plan reading, procurement, productivity analysis, public speaking, quality control, scheduling, structural analysis, temporary structures. Soft skill competencies include: analytic thinking, buy-in and advocacy, coaching, coping, delegation, facilitation, leadership, professional and ethical judgment, social awareness, systematic problem-solving, vision and goal-setting, working in partnership clients. Out of the above (Soft and Hard Skills), the ten competencies with the average results are ranked through top to down as shown follows: human resource leading, managing of construction tasks and procedures, technical ability and morally verdict, agreement or contract record and archive, perusal all project plan and specification, communication and conversation, capacity to manage and solve conflicts, disputes and problems, working in partnership with clients, 
performing the project with close coordination with customer, critical reasoning, time management.

\section{Conclusion}

It's obviously unequivocal that the essential factor for successful completion of a project within its constraints (scope, cost, time, and quality) is managers with high moral and best intellectual, emotional, managerial competencies whether it's a construction project or else, and no one can ignore this fact. Competencies (knowledge and skillsets) and leadership (social and influential power) styles are the outcomes of practice and performance experience which project managers achieved during the execution of the project over time and have a significant effect on the project's success. Managers would not be able to succeed at all, otherwise to consider leadership and management competencies. So, to conclude, it can be stated that, who want to be a successful construction project manager he/she must have at least the core competencies of leadership and management including technical, emotional, behavioral to cope with projects successfully.

\section{References}

1. Crawford L. Profiling the Competent Project Manager, Proj. Manag. Inst. 2000, 3-15.

2. Ahsan K, Ho M, Khan S. Recruiting project managers: A comparative analysis of competencies and recruitment signals from job advertisements, Proj. Manag. J. 2013;44:36-54. doi:10.1002/pmj.21366.

3. Stevenson DH, Starkweather JA, PM critical competency index: IT execs prefer soft skills, Int. J. Proj. Manag. 2010;28:663-671. doi:10.1016/j.ijproman.2009.11.008.

4. Raj PP, Baumotte ACT, Fonseca DPD, de LH, da Silva CM. Gerenciamento de pessoas em projetos 2010, 180.

5. Newton C. O̊Consultant, The competent manager: A model for effective performance 1983, doi:10.1016/0024-6301(83)90170-x.

6. Crawford L. Senior management perceptions of project management competence, Int. J. Proj. Manag. 23 (2005) 7-16. doi:10.1016/j.ijproman.2004.06.005.

7. [7] A.S. Hanna, M.W. Ibrahim, W. Lotfallah, K.A. Iskandar, J.S. Russell, Modeling Project Manager Competency: An Integrated Mathematical Approach, J. Constr. Eng. Manag 2016, 142 doi:10.1061/(ASCE)CO.1943-7862.0001141.

8. Ahmed S, Abdullahi AM. Leadership and project success in development sector, J. Econ. Manag 2017;305-19. doi:10.22367/jem.2017.30.01.

9. Wytyczne P, Ipma K, Baseline C. International Project Management Association, Management. 2006, 1-91.

10. Müller R, Turner JR. Attitudes and leadership competences for project success, Balt. J. Manag 2010;5:307-329. doi:10.1108/17465261011079730.

11. Orr EJ, Sneltjes C, Dai G. Best practices in developing and implementing competency models, Korn/Ferry Inst. 2010, 1-16.

12. Sherman RO, Bishop M, Eggenberger T, Karden R. Development of a leadership competency model, J. Nurs. Adm 2007;37:85-94. doi:10.1097/00005110200702000-00011.

13. International Project Management Association, Individual Competency Baseline for Project, Program and Portfolio Management 2015.
14. Crawford LH. Developing project management competence of individuals, Gower handbook of project management 4th edition, Gower Publ. $4^{\text {th }} 2007$.

15. McClelland DC. Testing for competence rather than for "intelligence"., Am. Psychol 1973;28:1-14. doi:10.1037/h0034092.

16. Hollenbeck GP, McCall MW, Silzer RF. Leadership competency models, Leadersh. Q. 2006;17:398-413. doi:10.1016/j.leaqua.2006.04.003.

17. Brière S, Proulx D, Flores ON, Laporte M. Competencies of project managers in international NGOs: Perceptions of practitioners, Int. J. Proj. Manag. 2015;33:116-125.

18. Müller R, Turner JR. Matching the project manager's leadership style to project type, Int. J. Proj. Manag 2007;25:21-32. doi:10.1016/j.ijproman.2006.04.003.

19. Rabechini Jr R. A importância das habilidades do gerente de projetos, Rev. Adm 2001;36:1-17.

20. Edum-Fotwe FT, McCaffer R. Developing project management competency: Perspectives from the construction industry, Int. J. Proj. Manag. 2000;18:111124. doi:10.1016/S0263-7863(98)90075-8.

21. Dulewicz V, Higgs M. Assessing leadership styles and organisational context, J. Manag. Psychol 2005;20:105123. doi:10.1108/02683940510579759.

22. Rose KH. Davidson J. Book Review: Project Management: A Managerial Approach, Seventh Edition, Proj. Manag. J. 2009;40:82-82. doi:10.1002/pmj.20135.

23. Loufrani-Fedida S, Missonier S. The project manager cannot be a hero anymore! Understanding critical competencies in project-based organizations from a multilevel approach, Int. J. Proj. Manag. 2015;33:12201235.

24. Cheng MI, Dainty ARJ, Moore DR. What makes a good project manager?, Hum. Resour. Manag. J. 2005;15:25-37. 8583.2005.tb00138.x.

25. Linda Geoghegan VD. Do Project Managers' Leadership Competencies Contribute to Project Success?, Proj. Manag. J. 2008;21:580. doi:10.1002/pmj.

26. Müller R, Turner R. Leadership competency profiles of successful project managers, Int. J. Proj. Manag 2010; 28:437-448. doi:10.1016/j.ijproman.2009.09.003.

27. LG. Flannes Steven W. People Skills for Project Managers 2001, 466.

28. Pinto JK, Kharbanda OP. Successful project managers : leading your team to success 1995;ix:421.

29. El-Sabaa S. The skills and career path of an effective project manager, Int. J. Proj. Manag 2001;19:1-7. doi:10.1016/S0263-7863(99)00034-4.

30. Munns AK, Bjeirmi BF. The role of project management in achieving project success, Int. J. Proj. Manag 1996;14:81-87.

31. Brill JM, Bishop MJ, Walker AE. The competencies and characteristics required of an effective project manager: A Web-based Delphi study, Educ. Technol. Res. Dev 2006;54:115-140. doi:10.1007/s11423-0068251-y.

32. Hartono B, Sulistyo S, Umam M. Leadership profiles of successful project managers in Indonesia, J. Ind. Eng. Manag 2019;12:274-301. doi:10.3926/jiem.2735. 
33. Higgs MJ, Dulewicz SV. The design of a new instrument to assess leadership dimensions and styles, Sel. Dev. Rev 2003;20:7-12.

34. Barkchian WR. Identification and Prioritization of Necessary Competencies for Construction Project Manager, Master's Degree Thesis, Ferdowsi Univ. Mashhad 2014.

35. Nidhra S, Dondeti J. The Project Manager's Leadership Style as a Success Factor on Projects: A Literature Review, Proj. Manag. J. 2012;2:29-50.

36. Rose KH. Book Review: Managing High Technology Programs and Projects, Third Edition, Wiley and Sons., New York 2003. doi:10.1177/875697280303400209.

37. Alvarenga JC, Branco RR, Guedes ALA, Soares CAP, da e Silva WS. The project manager core competencies to project success, Int. J. Manag. Proj. Bus 2019 doi:10.1108/IJMPB-12-2018-0274.

38. Galvin C, Gibbs T, Sullivan M, Williams J. Leadership Competencies of Project Managers: An Empirical Study of Emotional, Intellectual, and Managerial Dimensions, J. Econ. Dev. Manag. IT, Financ. Mark 2014;6:35-60.

39. Senthill M. Leadership Styles and Competencies of Project Managers in Successful Projects 2018. doi:10.1111/j.1467-8616.2008.00521.x Malik,

40. Clarke N. Leadership in projects: What we know from the literature and new insights, Team Perform. Manag. An Int. J doi:10.1108/13527591211241042.

41. Clarke N. Shared leadership in projects: A matter of substance over style, Team Perform. Manag 2012;18:196-209. doi:10.1108/13527591211241024.

42. Sudha KS, Shahnawaz MG, Farhat A. Leadership Styles, Leader's Effectiveness and Well-being: Exploring Collective Efficacy as a Mediator, Vision. 20 2016, 111-120. doi:10.1177/0972262916637260.

43. Delia Davila Quintana C, Mora Ruiz JG, Vila LE. Competencies which shape leadership, Int. J. Manpow. 2014;35:514-535.

44. Hassanzadeh M, Silong AD, Asmuni A, Abd Wahat NW. Global Leadership Competencies, J. Educ. Soc. Res. (2015). doi:10.5901/jesr.2015;5(2):137.

45. Cumberland DM, Herd A, Alagaraja M, Kerrick SA. Assessment and Development of Global Leadership Competencies in the Workplace: A Review of Literature, Adv. Dev. Hum. Resour. 2016;18301-317. doi:10.1177/1523422316645883.

46. Sethuraman K, Suresh J. Effective Leadership Styles, Int. Bus. Res. 7 doi:10.5539/ibr. 2014;7(9):165.

47. Meyer AM. What are the competencies of a successful project leader?, Int. J. Manag. Cases. 16 (2014) 29-36.

48. [48]P. Trivellas, C. Drimoussis, Investigating Leadership Styles, Behavioural and Managerial Competency Profiles of Successful Project Managers in Greece, Procedia - Soc. Behav. Sci 2013;73:692-700. doi:10.1016/j.sbspro.2013.02.107.

49. PMI, Project Management Body of knowledge (PMBOK) 2017. doi:10.1002/pmj.21345.

50. Alam M, Gale A, Brown M, Khan AI. The importance of human skills in project management professional development, Int. J. Manag. Proj. Bus 2010;3:495-516. doi:10.1108/17538371011056101.
51. Gillard S. Soft Skills and Technical Expertise of Effective Project Managers, Proc. 2009 In SITE Conf. 2009, 6. doi:10.28945/3378.

52. Muzio E, Fisher DJ, Thomas ER, Peters V. Soft Skills Quantification (SSQ) Foi Project Manager Competencies, Proj. Manag. J. 2007;38:30-38. doi:10.1177/875697280703800204.

53. Gillard S, Price J. The Competencies of Effective Project Managers: A Conceptual Analysis, Interantional J. Manag 2005;22:48-54.

54. Abbott D, Brown S, Wilson G. Development Management As Reflective Practice, J. Int. Dev 2007.

55. Cerimagic S. Influence of culture on project practices, Educ. Bus. Soc. Contemp. Middle East. 2010;3:277288. doi:10.1108/17537981011089578.

56. Nicholas Clarke, Emotional intelligence and its relationship to transformational leadership and key project manager competences, Proj. Manag. J. 2011;41:5-20.

57. Cocco AF. Using performance goals to motivate workers: a practical guide for project managers, Proj. Manag. J 1995.

58. Amadou D, Denis T. The success of international development projects, trust and communication: an African perspective, Int. J. Proj. Manag 2005;23:237252.

59. Henderson LS. The Impact of Project Managers' Communication Competencies: Validation and Extension of a Research Model for Virtuality, Satisfaction, and Productivity on Project Teams, Proj. Manag. J. 2008;39:48-59. doi:10.1002/pmj.20044.

60. Lee Y, Calvez V, Guénette AM, La compétence culturelle: S'équiper pour les défis du management international 2007.

61. Leybourne S, Sadler-Smith E. The role of intuition and improvisation in project management, Int. J. Proj. Manag. 2006;24:483-492. doi:10.1016/j.ijproman.2006.03.007.

62. Moodian M. Contemporary Leadership and Intercultural Competence: Exploring the Cross-Cultural Dynamics within Organizations, Contemp. Leadersh. Intercult. Competence Explor. Cross-Cultural Dyn. within Organ 2009.

63. PM4NGOs, A Guide to the PMD Pro - Project Management for Development Professionals Guide, 2010, 155 .

64. Skulmoski GJ, Hartman FT. Information systems project manager soft competencies: A project-phase investigation, Proj. Manag. J 2010;41:61-80. doi:10.1002/pmj.20146.

65. Grisham T, Walker DHT. Cross-cultural leadership, 2008. doi:10.1108/17538370810883873.

66. Liikamaa K. Developing a Project Manager's Competencies: A Collective View of the Most Important Competencies, Procedia Manuf 2015;3:681687.

67. Liikamaa K. Tacit Knowledge and Project Manager's Competences: A Ph.D. Thesis, Tampere Univ. Technol 2006.

68. Laufer A, Hoffman EJ, Russell JS, Cameron WS. What successful project managers do, MIT Sloan Manag. Rev 2015;56:43-51. doi:10.1109/emr.2015.7123232.

69. Ahadzie DK, Proverbs DG, Sarkodie-Poku I. Competencies required of project managers at the 
design phase of mass house building projects, Int. J. Proj. Manag. 2014;32:958-969. doi:10.1016/j.ijproman.2013.10.015.

70. Zhang F, Zuo J, Zillante G. Identification and evaluation of the key social competencies for Chinese construction project managers, Int. J. Proj. Manag 2013;31:748-759. doi:10.1016/j.ijproman.2012.10.011.

71. Boyatzis RE. The Emotional Competence Inventory (ECI). In G. Geher (Ed.), Nov. Sci. Publ 2004;5:53-68.

72. Thal AE, Bedingfield JD. Successful project managers: An exploratory study into the impact of personality, Technol. Anal. Strateg. Manag 2010;22:243-259. doi:10.1080/09537320903498587.

73. Andoh-Baidoo FK, Villarreal MA, Koong KS, Cornejo $\mathrm{H}$, Schmidt $\mathrm{N}$, Colunga $\mathrm{H}$ et al, Key competencies for global project managers: A cross cultural study of the UK and India, Int. J. Bus. Syst. Res 2011;5:223-243. doi:10.1504/IJBSR.2011.039294.

74. Brewer JL. Project managers: Can we make them or just make them better?, Proc. 6th Conf. Inf. Technol. Educ. Sigite 2005, 167-173. doi:10.1145/1095714.1095754.

75. Hudson K, Moussa N. The skills of an information technology project manager- Do project management competency standards have what it takes?, Proj. Perspect 2006;XXVIII:92-95.

76. Keil M, Napier NP, Tan FB. IT project managers' construction of successful project management practice: a repertory grid investigation, Inf. Syst. J. 2007;19:255282.

77. Reich BH, Sauer C, Wee SY. Innovative practices for IT projects, Inf. Syst. Manag. 2008;25:266-272. doi:10.1080/10580530802151210.

78. Sukhoo A, Barnard A, Eloff MM, Van Der Poll JA. An Assessment of Software Project Management Maturity in Mauritius, Issues Informing Sci. Inf. Technol 2005;2:671-690. doi:10.28945/859.

79. Obradovic V, Jovanovic P, Petrovic D, Mihic M, Mitrovic Z. Project Managers' Emotional Intelligence A Ticket to Success, Elsevier B.V 2013. doi:10.1016/j.sbspro.2013.03.034.

80. Zachary WB, Krone RM. Managing Creative Individuals in High-Technology Research Projects., IEEE Trans. Eng. Manag. EM-31 1984, 37-40. doi:10.1109/TEM.1984.6447556.

81. Thoms P, Kerwin JJ. Leadership of Project Teams, Wiley Guid. to Manag. Proj 2007, 1014-1032. doi:10.1002/9780470172391.ch40.

82. Prabhakar GP. What is Project Success: A Literature Review, Int. J. Bus. Manag. doi:10.5539/ijbm. 2009;3(9):3-10.

83. Zimmerer TW, Yasin MM, A Leadership profile of American project managers, IEEE Eng. Manag. Rev. 1998;26:5-11. doi:10.1177/875697289802900107.

84. Robert L, Henry MC. Understanding the project manager competencies in a diversified project management community using a project management competency value grid, A PHD Disseration المجلد. 2008;49:73-69.

85. Pierce C. Executive Competencies: Research Issues, Activities and Responses, Exec. Dev 1994;7:18-20. doi:10.1108/09533239410061815.

86. Ahadzie DK, Proverbs DG, Olomolaiye PO, Ankrah NA. Competencies required by project managers for housing construction in Ghana: Implications for CPD agenda, Eng. Constr. Archit. Manag 2009;16:353-375. doi:10.1108/09699980910970842.

87. Casey Cline R. Teaching key competencies of effective construction project Managers to adults in higher education, Idoha 2008. 